\title{
An Evaluation of the Intensive Care Unit Resources and Utilization in Two Governmental Hospitals in Tripoli, Libya
}

\author{
Ahmed Atia $^{{ }^{*} \text {, Abdulsalam Ashur }}{ }^{1}$, Hosam Elmahmoudi ${ }^{1}$, Ahmed Abired ${ }^{2}$, Nafisa Bkhait $^{3}$, \\ ${ }^{1}$ Department of anaesthesia and intensive care, Faculty of Medical technology, Tripoli University, \\ Tripoli, Libya. \\ ${ }^{2}$ Department of Basic Medical Science, Tripoli Higher Institute for Medical Professions, Tripoli, \\ Libya. \\ ${ }^{3}$ Department of Pharmacy, University of Tripoli Alahlia, Janzur, Libya
}

Received: 18 April 2019/ Accepted: 15 November 2019

Doi: https://doi.org/10.54172/mjsc.v34i3.241

\begin{abstract}
The growing population in Tripoli is projected to have a sustained increase in the demand for health services, especially in-service areas with limited resources such as intensive care units (ICUs). Currently, ICUs in the city of Tripoli routinely operate at or near full capacity and have a limited ability to accommodate the next critically ill patient. This disparity in demand and supply makes a substantial strain on our health care system. In response to this rising problem, the current study aimed to investigate the ICU capacity in the two largest hospitals in Tripoli, Libya. This is a retrospective observational study that conducted to compare ICU capacities and admission in the Medical intensive care unit (MICU) and surgical intensive care unit (SICU) of Tripoli Medical center (TMC) and Alkhadra hospital (AH) in Tripoli city of Libya. ICUs capacity and admissions were assessed and recorded in data collection sheet that includes; type of ICU, number of available ICU beds, number of available functional monitors, number of available functional mechanical ventilators, number of patients admitted to the ICU, and number of ICU nurse. In TMC, MICU occupied with 4 beds, 4 monitors, 3 mechanical ventilators (MV), 5 patients admitted, and 13 nurses. Whereas SICU engaged with 4 beds, 5 monitors, $5 \mathrm{MV}, 13$ patients admitted and 15 nurses. While MICU at AHT was occupied with 4 beds, 4 monitors, $1 \mathrm{MV}$, and 4 admitted patients with 1 nurse care, SICU at CHT was comprised of 3 beds, 3 monitors, $0 \mathrm{MV}$, and 3 patients with 1 nurse stuff. We concluded that facilities at both MICU and SICU at Alkhadra hospital of Tripoli were less efficient than MICU and SICU at Tripoli Medical centre. Both ICUs at AHT had not enough beds, observation equipment, and nursing staff to take care of patients. However, facilities of both ICUs at TMC were also not sufficient.
\end{abstract}

Keywords: ICU; Medical; Surgical; Patient.

\section{INTRODUCTION}

Even with a high burden of serious illness in lower-middle-income and low-income countries (Adhikari, Fowler, Bhagwanjee, \& Rubenfeld, 2010; Dondorp, Iyer, \& Schultz, 2016), handling critically ill patients faces serious challenges in these regions of the world. The inadequate intensive care unit (ICU) services that exist are often suffering from a shortage of bed capacities, physicians, and nurses with definite preparation in intensive care, as well as material resources (Baelani et al., 2011; Baker et al., 2013). This often consequences in inadequate care linked with elevated mortality rates and adverse long-term (Dünser et al., 2008; Frikha et al., 2005; Kwizera et al., 2016). Critical care treatments in Libya is new and underdeveloped medical field. While studies have

*Corresponding Author: Ahmed Atia ah.atia@uot.edu.ly, Department of Anesthesia and Intensive Care, Faculty of Medical Technology, Tripoli University, Tripoli, Libya. 
reported comparable limitations in sufficiently trained ICU staff and material resources as stated in other resource-restricted situations (Dünser et al., 2009; Jochberger et al., 2010), a paucity of data on the capacity of ICU beds and the burden of critical illness in Libya exist so far.

Knowing the availability of ICU beds and their sufficiency in the country could be of benefit to recognize and prioritize approaches to enhance the care of critically ill patients in Libya. In this study, we sought to statistically compare the ICU capacity and the number of ICU admissions between the two largest Medical centers in the city of Tripoli, Libya.

\section{MATERIALS AND METHODS}

This is a retrospective observational study conducted to observe ICU capacities and admissions in a Medical intensive care unit (MICU) and surgical intensive care unit (SICU) of two governmental hospitals in Tripoli, Libya during March 2018. This study was endorsed by the committee of the faculty of Medical technology, Tripoli University, Libya. ICUs capacity and admissions were assessed and recorded in a data collection sheet that includes; types of ICU, number of available ICU beds, number of available functional monitors, number of available functional mechanical ventilators, number of patients admitted to the ICU, and number of
ICU nurses. Intensive care units (ICUs) are specially equipped hospital units that provide highly specialized care to patients who suffer from serious injuries or illness. A multidisciplinary team (physicians, nurses, respiratory therapists, pharmacists) trained to take care of critically ill patients and provide continuous observation and monitoring as well as specialized care. In the current study, we compared the mentioned facilities in MICU and SICU in the two selected hospitals. The comparison between MICU and SICU was made using excel sheets.

\section{RESULTS}

Data from both ICUs in this study are shown in figures $1 \& 2$ respectively. A total of 4 ICUs were included in this study. Of these, 2 ICUs (1 SICU and $1 \mathrm{MICU}$ ) were in Tripoli Medical center [TMC], and the other two ICUs (1 SICU and $1 \mathrm{MICU}$ ) were in Alkadra hospital of Tripoli [AHT]. In TMC, MICU has 4 beds, 4 monitors, 3 mechanical ventilators (MV), 5 patients admitted, and 13 nurses. Whereas SICU occupied with 4 beds, 5 monitors, $5 \mathrm{MV}, 13$ patients admitted, and 15 nurses. On the other hand, MICU in AHT were occupied with 4 beds, 4 monitors, $1 \mathrm{MV}, 4$ patients admitted, and 1 nurse while SICU had 3 beds, 3 monitors, $0 \mathrm{MV}, 3$ patients admitted, and 1 nurse.

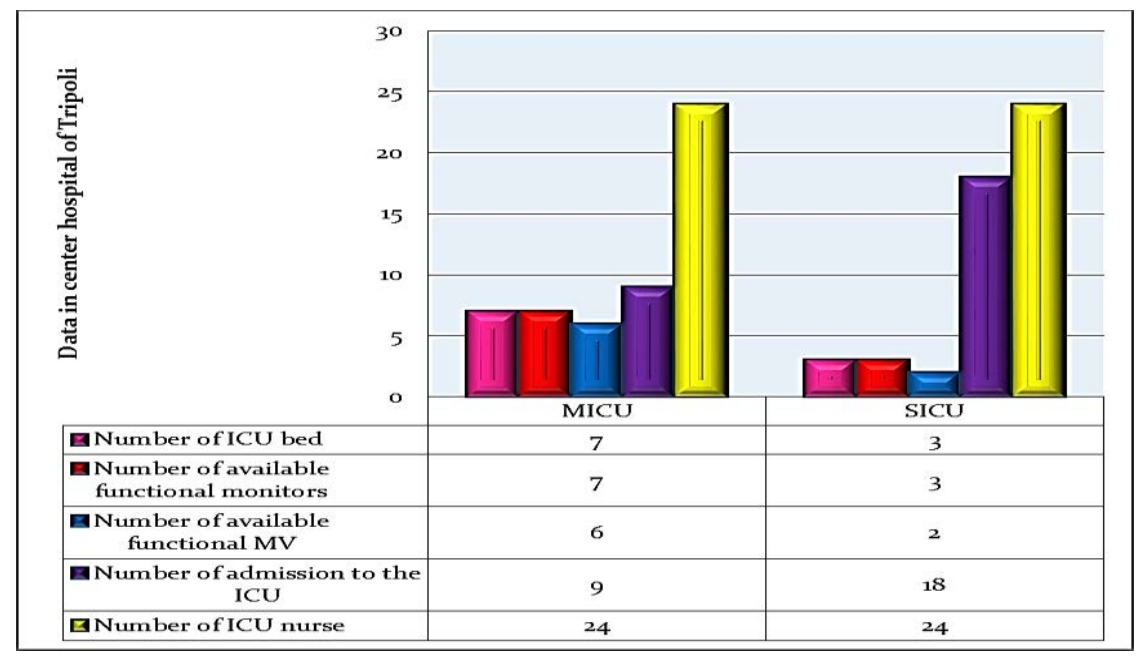

Figure: (1). Comparison between MICU and SICU at CHT

(C) 2019 The Author(s). This open access article is distributed under a CC BY-NC 4.0 license. ISSN: online 2617-2186 print 2617-2178 
Our results in this study reported that the number of beds in MICU at AHT was 4 beds while the number in MICU at TMC was 4 beds. MICU at AHT had 4 monitors and 1 ventilator compared to 4 monitors and 3 ventilators at TMC . The admission number at TMC was more than that for AHT ( 5 to 4 patients, respectively). For the nursing staff, we found that the number of nursing staff in the AHT was less than that for the MICU at TMC $(1,13$ respectively). SICU data represented low facilities compared to MICU. For SICU at AHT, the number of admissions were high (3) compared to the facilities ( 3,2 monitors to ventilators), and the nursing staff were insufficient to take care of these patients $(n=1)$. At TMC, the SICU equipments were more likely to be sufficient with the admission number. The numbers of functional ventilators and monitors were 5 and 5 , while the admission number was 13 with total care of 13 nurses.

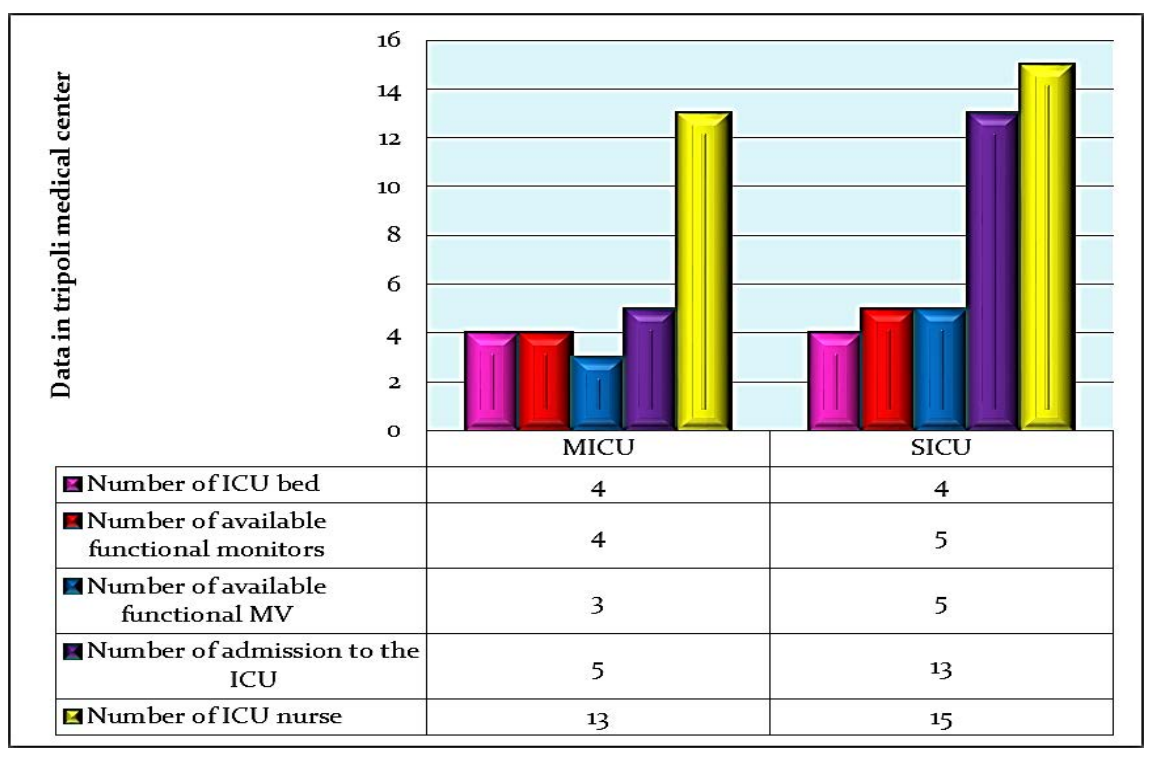

Figure: (2). Comparison between MICU and SICU at TMC

When we compare between the MICU and SICU at AHT, we found that the number of beds for MICU were more than that for SICU, and the number of surveillance devices were more suitable for MICU than SICU while the- number of ventilators was more suitable for MICU than for SICU. Moreover, the number of nursing staff for MICU and SICU was equal. Instead, the facilities in MICU and SICU at TMC were mostly equal (Figures $3 \& 4$ ).

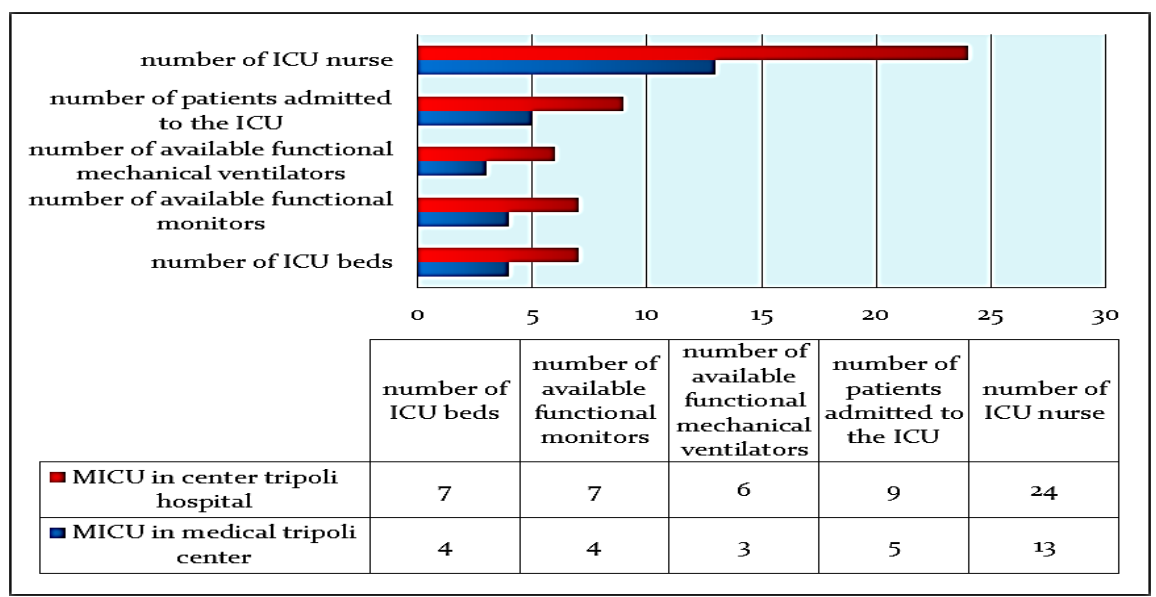

Figure: (3). Comparison of MICU facilities between CHT and TMC

(C) 2019 The Author(s). This open access article is distributed under a CC BY-NC 4.0 license. 


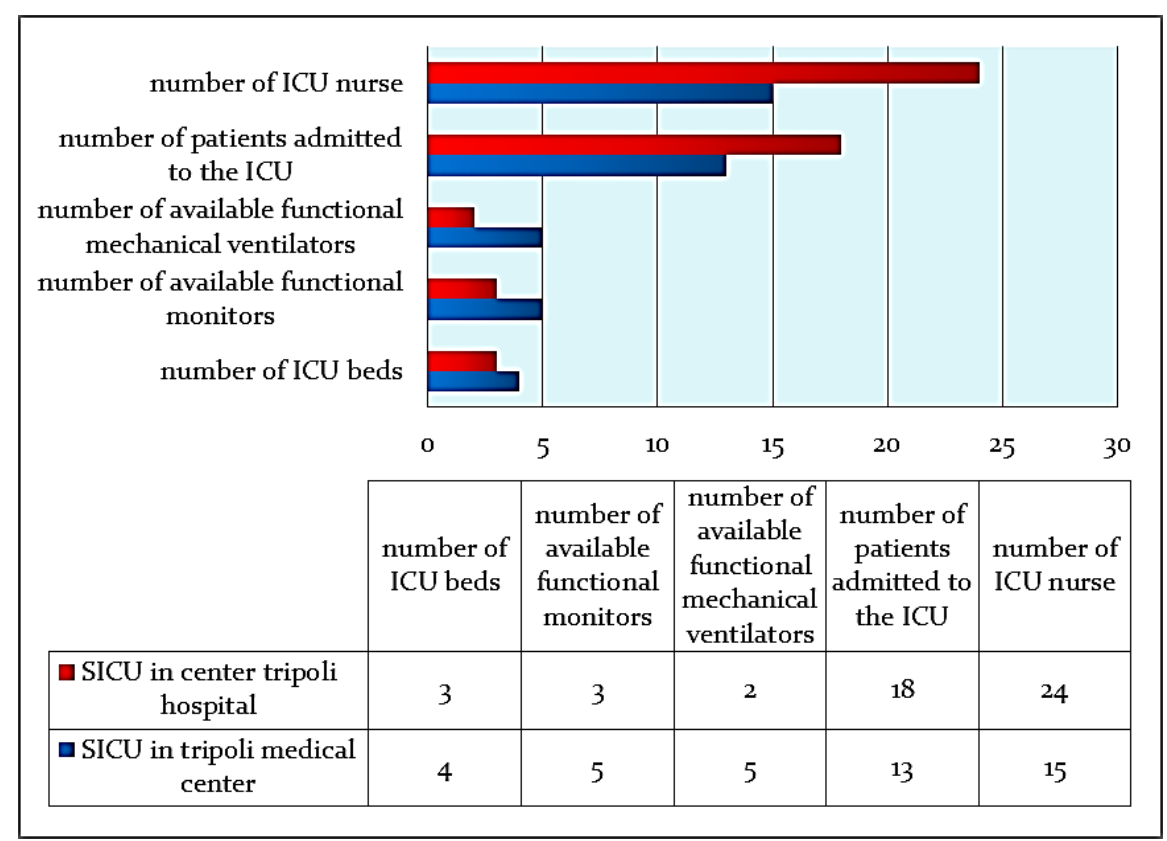

Figure: (4). Comparison of SICU facilities between CHT and TMC

\section{DISCUSSION}

This study identified 4 ICUs within two hospitals in the city of Tripoli, Libya. SICU data represent low facilities as compared to MICU. For SICU at CHT, the number of admissions was high $(n=18)$ as compared to the facilities $(3,2$ monitors to ventilators), but the nursing staff was sufficient to take care of these patients $(n=24)$. These results could be attributed to a relevant shortage of resources in Libyan ICU services. Indeed, previous studies highlighted substantial resource restrictions in ICUs of other settings (Dünser et al., 2009).

Our results clearly showed that in, Both ICUs, there was a shortage in bed numbers. This study in consistence with a study done in Uganda, which reported a limited number of ICU beds in as a whole - only one ICU bed for every one million Ugandans or 0.1 ICU beds/100,000. This also compares poorly with South Africa (8.9/100,000), Sri Lanka (1.6/ $100,000)$, and the United States of America (20/100,000) (Adhikari et al., 2010; Dubowitz, Detlefs, \& McQueen, 2010; Hodges et al., 2007).
Limitations of this study include its retrospective nature with the consequence that it could not provide the same level of evidence as a prospective survey. Furthermore, due to the concise format of medical records, only limited data could be retrieved for this audit.

More detailed data may have allowed for a precious examination of ICU facilities and other variables associated with admission. It is hoped that advances in health information technology in low-income countries will result in improved reporting ability in the future.

\section{CONCLUSION}

Critical care remains an ignored zone of health care system in this setting. A large number of patients with possibly treatable situations are still not having access to such services. Additional prospective study to evaluate the resources is required to design suitable units in such settings, and the influence on morbidity and mortality, particularly for the most common situations is worth.

\section{ETHICS}

This study was approved by the committee of 
the faculty of Medical technology, Tripoli University, Libya. The authors declare that they have no competing interests.

\section{REFERENCES}

Adhikari, N. K., Fowler, R. A., Bhagwanjee, S., \& Rubenfeld, G. D. (2010). Critical care and the global burden of critical illness in adults. The Lancet, 376(9749), 1339-1346 .

Baelani, I., Jochberger, S., Laimer, T., Otieno, D., Kabutu, J., Wilson, I . . . ‘.Dünser, M. W. (2011). Availability of critical care resources to treat patients with severe sepsis or septic shock in Africa: a self-reported, continent-wide survey of anaesthesia providers. Critical care, 15(1), R10 .

Baker, T., Lugazia, E., Eriksen ‘J., Mwafongo, V., Irestedt, L., \& Konrad, D. (2013). Emergency and critical care services in Tanzania: a survey of ten hospitals. BMC health services research, 13(1), 140 .

Dondorp, A. M., Iyer, S. S., \& Schultz, M. J. (2016). Critical care in resourcerestricted settings. Jama, 315(8), 753754 .

Dubowitz, G., Detlefs, S., \& McQueen, K. K. (2010). Global anesthesia workforce crisis: a preliminary survey revealing shortages contributing to undesirable outcomes and unsafe practices. World journal of surgery, 34(3), 438-444 .

Dünser, M. W., Bataar, O., Tsenddorj, G., Lundeg, G., Jochberger, S., \& Jakob, S. (2009). Intensive care medicine in Mongolia's 3 largest cities: outlining the needs. Journal of critical care, 24(3), 469. e461-469. e466.
A., \& Hasibeder, W. R. (2008). Differences in critical care practice between an industrialized and a developing country. Wiener klinische wochenschrift, 120(19-20), 600-607 .

Frikha, N ‘.Mebazaa, M., Mnif, L., El, N. E., Abassi, M., \& Ben, M. A. (2005). Septic shock in a Tunisian intensive care unit: mortality and predictive factors. 100 cases. La Tunisie medicale, 83(6), 320-325 .

Hodges, S., Mijumbi, C., Okello, M., McCormick, B., Walker, I., \& Wilson, I. (2007). Anaesthesia services in developing countries: defining the problems. Anaesthesia, 62(1), 4-11 .

Jochberger, S., Bataar, O., Mendsaikhan, N., Grander, W., Tsenddorj, G., Lundeg, G., \& Dünser, M. W. (2010). Anesthesia care in a medium-developed country: a nationwide survey of Mongolia. Journal of clinical anesthesia, 22(6), 443-449 .

Kwizera, A., Tumukunde, J., Ssemogerere, L., Ayebale, E., Agaba, P., Yakubu, J., . . . Kalyesubula, R. (2016). Clinical Characteristics and 30-Day Outcomes of Intermittent Hemodialysis for Acute Kidney Injury in an African Intensive Care Unit. BioMed research international, 2016.

Dünser, M. W ‘.Bataar, O., Tsenddorj, G., Lundeg, G., Torgersen, C., Romand, J.- 


\title{
تقييم موارد وحدة العناية المركزة واستخدامها في مستثفيين حكوميين في طرابلس، ليبيا
}

\author{
احمد عطية1**، عبد السلام عاشور، حسام المحمودي، احمد عبيريد²، نفيسة بخيث33 \\ 1 قسم التخدير والعناية الفائقة، كلبة التقنبة الطبية، جامعة طرابلس، طرابلس، ليييا

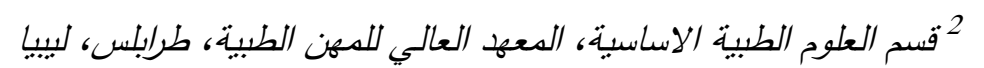

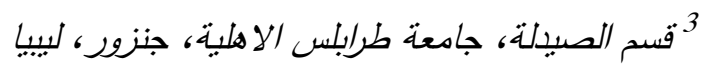

تاريخ الاستلام: 18 أبريل 2019 / تاريخ القبول: 15 نوفمبر 2019 https://doi.org/10.54172/mjsc.v34i3.241:Doi

المستخلص: من المنوقع أن زيادة عدد السكان في طرابلس سنتهد زيادة مستمرة في الطلب على الخدمات الصحية، وخاصة في مناطق الخدمات ذات الموارد المحدودة مثل وحدات العناية المركزة حاليًَا، تعمل وحدات العناية المركزة في مدينة طرابلس، ليبيا بشكل روتيني بكامل طاقتها أو بالقرب منها ولديها قدرة محدودة على استيعاب المريض المصاب بأمراض خطيرة. هذا التباين في

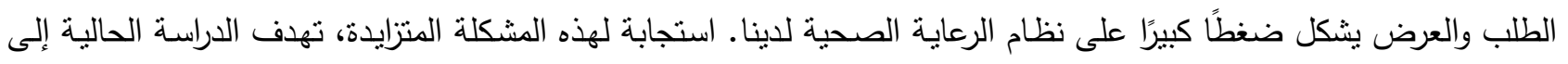

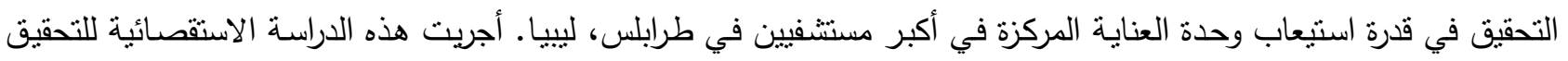

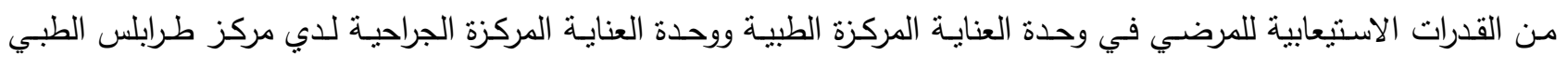

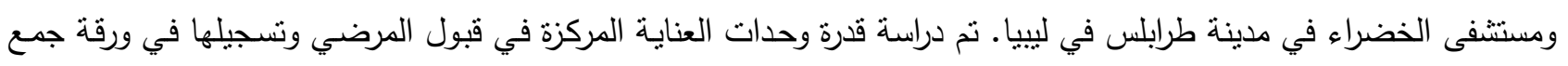

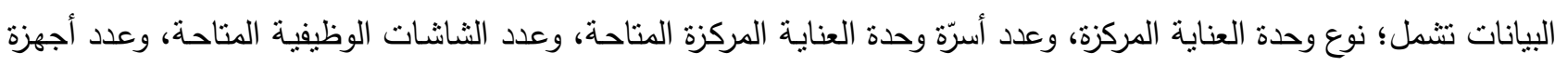

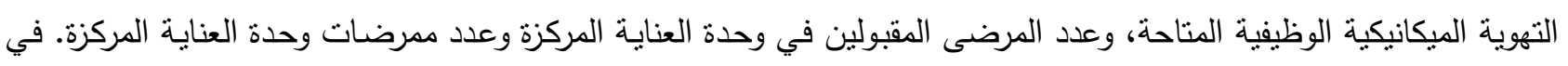
مركز طرابلس الطبي، احتلت وحدة العنايـة المركزة الطبيـة 4أسـرّة و 4 شاشـات و 3 أجهزة تهويـة ميكانيكيـة و 5 مرضسى و و 13 ممرضة. في حين، وحدة العنايـة المركزة الجراحية توفرت بها 4 أسرّة، 5 شاشـات، 5 أجهزة تهويـة ميكانيكية، 13 مريضـا و 15 ممرضة. بينما احتلت وحدة العناية المركزة الطبية في مستشفى الخضراء 4 سرير، 4 شاشات مراقبة، 1 أجهزة تهوية ميكانيكية و 4 وليكة مرضي مـع 1 ممرضة الرعاية. وحدة العناية المركزة الجراحية في مستشفى الخضراء تحوي 3 أسرّة، 3 شاشـات، 0 أجهزة تهوية ميكانيكية، و 3 مرضى مع 1 ممرضة. نستتنج ان المرافق في كل من وحدة العناية المركزة الطبية ووحدة العناية المركزة الجراحية

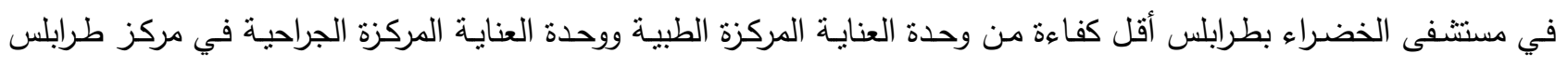

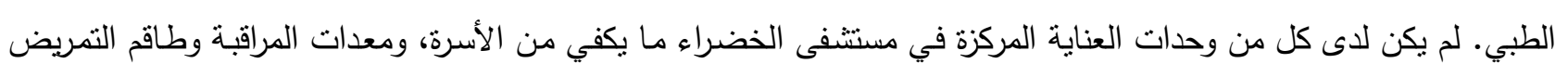
لرعاية المرضى. ومع ذلك، لم تكن مرافق كل من وحدات العناية المركزة في مركز طرابلس الطبي كافية.

الكلمات المفتاحية: وحدة العناية الفائقة؛ طبي؛ جرحي؛ مرضي.

"احمد عطبةah.atia@uot.edu.ly قسم التخدير والعناية الفائقة، كلية التقنية الطبية، جامعة طر ابلس، طر ابلس. 